1994

\title{
Spain on Status and Space: A Comment
}

\author{
James J. Chriss \\ Cleveland State University
}

Follow this and additional works at: https://engagedscholarship.csuohio.edu/clsoc_crim_facpub

Part of the Criminology Commons

How does access to this work benefit you? Let us know!

\section{Repository Citation}

Chriss, James J., "Spain on Status and Space: A Comment" (1994). Sociology \& Criminology Faculty Publications. 96.

https://engagedscholarship.csuohio.edu/clsoc_crim_facpub/96

This Article is brought to you for free and open access by the Sociology \& Criminology Department at EngagedScholarship@CSU. It has been accepted for inclusion in Sociology \& Criminology Faculty Publications by an authorized administrator of EngagedScholarship@CSU. For more information, please contact library.es@csuohio.edu. 


\title{
Spain on Status and Space: $A$ Comment
}

\author{
JAMES J. CHRISS \\ University of Pennsylvania
}

\section{A QUESTION OF CAUSALITY}

Daphne Spain $(1992,1993)$ has marshaled a great deal of evidence which suggests a correlation between women's low social status in relation to men's and the degree of spatial gender segregation. Specifically, she hypothesizes that the lower a woman's status in a society, the greater the degree of spatial segregation that may be observed between women and men in that society. This physical exclusion of women from men's spaces helps to perpetuate or exacerbate women's low status and subjugation primarily by keeping women from acquiring the types of socially valued knowledge that traditionally has remained sequestered in men's spheres of influence; these are schools, the workplace, and, to a lesser extent, the household (also see Comaroff and Comaroff 1991, pp. 13253; England and Browne 1992).

The main problem with Spain's argument, as I see it, is that she remains too noncommittal when she states the following near the end of the paper: "Positing neither cause nor effect, the spatial perspective points out the reciprocity between status and space" (1993, p. 137). I would suggest, however, that logically, this relationship can only be unidirectional, at least initially. That is, spatial segregation could not or would not occur before some conceptualization or awareness of a status system, but only after such a determination has been made and is operating in a community or society.

Let us consider the problem in this way. Try to imagine a human society in which gender segregation exists-architectural or geographic-which does not involve some prior determination, by one group, that the other is of lower worth or value. Even in the primordial human group we would have to say that if spatial segregation were observed, there would have to be some reason for the existence of this social arrangement, whether biological, cultural, or some other. ${ }^{1}$ That is, it appears that some antecedent favor always will exist to precipitate whatever spatial segregation exists between males and females.

\section{RECURSIVITY IN THE RELATIONSHIP}

Perhaps I am misreading Spain here. She may well be arguing that in fact status does "cause" spatial segregation between the sexes, insofar as the temporal order of this relationship seems obvious (as outlined above). Perhaps, then, she remains noncommittal on the seemingly recursive nature of the relationship. In other words, because we agree that status considerations precede or lead to the behavior associated with gendered space, it may well be the case that once the status system is firmly in place, and in concert with

${ }^{1}$ From the sociological perspective, the possibility or idea of a biological basis for gender segregation is not likely to be considered seriously. Territorialty, however, an ethological concept, has been applied to the study of the spatial regulation of behavior among humans more generally (see, e.g., Chriss 1993; Goffman 1971, Vine 1975) Nonetheless, it remains unclear to what extent terntoriality may be useful or appropriate to the analysis of spatial gender segregation. 
other factors, a feedback loop is created, whereby the mere evidence or reality of gendered spaces validates the notion that women indeed occupy a lower status than men.

This position reflects Spain's adherence to structuration theory (e.g., Bourdieu 1989; Giddens 1984; Pred 1981). The question of the causal direction of the relationship, narrowly understood, is less important than addressing "the ways in which status differences are maintained (once in place) by the spatial relationships between men and women" (Spain 1992, p. 28). Again, however, Spain need not leave it at that. Various social scientists' discussions of causality and sequencing of (inter)action, such as Fararo's and Skvoretz"s expectation states theory (e.g., Fararo 1939; Fararo and Skvoretz 1986; also sce Collins 1987; Wallace 1987), may help to point toward a further specification of causality in, and the recursive nature of, the relationship.

Expectations state (E-state) theory suggests that "current behavior is a function of the actor"s expectation state and information input" (Fararo 1989. p. 185). Hence, when actors are presented with the reality of gendered spaces and have become accustomed to this arrangement between the sexes (Goffman 1977), their expectations and assumptions regarding women's low status in relation to men are reinforced. This recursivity thereby maintains both gendered spaces and the perception of women's lower status.

Holding in abeyance the possibility of a biological basis for spatial gender segregation, we have here a classic case of culture "causing" or producing social structure, whereby the seemingly obdurate reality of this social structure-gendered spaces-reinforces through feedback the cultural norms and values concerning women's subordinate status. This point is consistent not only with explanations provided by E-state structuralism. but also with Wallace's (1987) discussion of two-way causal sequencing and with Collins's (1987) own micro-macro theory, namely interaction rtual chains. As Collins explains.

All social structure is enacted; 1:s empirical reality consists of individual actions, thoughts, and face-fo-face encounters. What makes it macro-which is to say, gives it the repetitrveness that we mean by "structure." is the way these micro events are linked together in patterns across time and space $(987,0.47)$

This recursivity, however, should not keep us from recognizing that logically, and in the original state of affairs, determinations of status (i.e., culture) are antecedent to gendered spaces (i.e., social structure).

\section{A LOOK AT DEGENDERING SPACES}

The spatial segregation of women at the macro or social structural level. as described by Spain, tells a grim tale of the everyday experiences of these women at the micro level, especially with regard to what happens-or rather, doesn't happen-in face-to-face interaction. Cut off from the spaces in which socially valued knowledge is produced and protected (argely by men), women are blocked from engaging in the forms of interaction through which such knowledge may be enacted or received. Writers such as Unger (1975) and Manicas (1974) argue that the ideal community, wherein heterogeneity is celebrated and in which the forces of racism, sexism, and homophobia do not operate to devalue certain groups, can be realized only if face-to-face interaction anong members is assured in various contexts.

Spain's idea of degendering spaces is an attempt to subvert the privileged, traditionally male-dominated cloisters of face-to-face interaction wherever these interactions take place: in the boardroom, the classroom, and even the bedroor. Likewise, theorists of community 
are inclined to privilege or champion face-to-face interaction as a safeguard of democracy and the good society. As Young states,

All [theorists of community] give primacy to face-to-face presence because they claim that only under those conditions can the social relations be immediate. . . Immediacy also here means relations of co-presence in which persons experience a simultaneity of speaking and hearing and are in the same space, that is, have the possibility to move close enough to touch (1990, pp. 313-14).

Young argues, however, against the importance of immediacy in assuring community and the good life. She points out (rightly, I believe) that all communication is mediated and is susceptible to distortion (Habermas 1984), whether it takes place face-to-face or over much greater distances. Separation often is equated with violence, with alienation. From the community perspectıve, instruments of mediation, such as bureaucracy and even the mass media, actually are agents of alienation, commodification, and dehumanization because they establish (or make possible) the spatial segregation of various groups or peoples; thereby they mute or make less relevant the energizing character of face-to-face interaction (also see Dean 1992).

The way in which information is mediated, protected, or otherwise controlled in faceto-face encounters has been described at great length by Goffman (e.g., 1959, 1969, 1974, 1981). His work illustrates how far off the mark, and even how idealistic, are the representatives of the latter position-Spain included. Degendering spaces along the lines conceptualized by Spain perhaps will bring greater status to women, but only as far as the realities of face-to-face interaction will allow. Yet even if women someday attain parity in regard to spatial arrangements, they are not likely to attain equal status with men until they acquire the cultural capital that will allow them to engage in the subtle nonverbal communications which currently are men's province.

I will not belabor the point here, but certainly men are capable of engaging in certain forms of verbal and nonverbal behavior in which women cannot (or would not) engage to similar effect, or which are downright threatening to women (but not necessarily to men). A woman simply cannot return in kind something as simple as a raised eyebrow, a smile, a lick of the lip, or certain forms of eyework (e.g., leering, gazing at a particular part of the body) performed by a man toward a woman - that is, the whole litany of subtle sexual posturings that are possible in the workplace or elsewhere. ${ }^{2}$ In effect, all other things being equal, women do not yet have the cultural capital with which to engage men as equals in sexual banter, innuendo, or other such behavior falling under the rubric of sexual politics (see, e.g., Collins et al. 1993). ${ }^{3}$

\footnotetext{
2 An example should suffice to make my point. At a constructıon site a group of male laborers were taking their lunch break; some were sitting against the face of the building. others atop assorted scaffoldings and support beams. Any woman who happened to walk past invariably received a loud round of whistles, hoots, and other assorted "street comments" (Gardner 1983). Although the men's pleas and invitations went unacknowledged by the majority of women. most women appeared to be annoyed by the men's rude displays. On one occasion, however, a woman responded to a particularly loud and obnoxious wolf whistle with one of her own. After completing the whistle. she turned toward the offending whistler and shouted in a mocking, exaggerated tone, "Oooh, baby!" What happened next? A few of the men approached the woman, inviting her to "put her money where her mouth is." The woman had no alternative but to walk off, shaking her head and proclaiming, "You assholes just will never get it, will you?" This vignette illustrates the simple fact that a woman cannot, or would choose not to, engage in certain forms of "male" behavior lest she be drawn into lines of action-such as acceptung an invitation from a man, however insincere, or offering one herself-which she probably would not welcome.

3 This is not to say that concerted efforts have not been made to level the playing field in this regard. We witness, for example, the imbroglio that has erupted around the problem of sexual harassment, or harassing speech more generally (see Strauss 1990). The confirmation hearings of Clarence Thomas became the focal point of the controversy, as Anita Hill's sensational allegations of sexual harassment by Thomas apparently
} 
That the workplace is not a suitable place for men to enact such behaviors is not the issue; men probably will always be onented to the pursuit of women, whether in a serious or more playful (flirtatious) veir. The promise of degendered spaces will not be fulfilled until men perceive women as equally threatening terms of the possibility of taking certain lines of action, especially those which conld be construed as implying sexual interest

\section{REFERENCES}

Bourdieu. Pierre. 1989 "Social Space and Symbolic Power" Sociological Theory 7(1). 14-25.

Cinns, James I. 1993 "Looking Back on Goffman. The Excavation Continues." Human Studies 16(4.) 46983

Colins. Rardail. 1987. "A Micro-Macro Theory of Intellectca: Creatrvty" The Case of German Idealst Philosophy " Soctological Theory 5(1): 47-69

Colluns, Randai!. Janet Saltzman Chaietz, Rae Lesser Blumberg, Scott Coltrane. and Jonathan H. Turner 1993

"Toward an Integrated Theory of Gender Stratification" Sociologicai Perspectives 36(3)' 185-216.

Comaroff, Jean and John Comaroff 1991. Of Revelation and Revolution. Christiantiv, Colonialism, and Consciousiness in South Africa, Vol 1. Chicago University or Chicago Press

Dean, Joci. 1992. "Including Women. The Consequences and Side Effects of Femınist Critiques of Civil Society" Phulosophy and Soctal Cruticusm 18(3/4): 378-406.

England, Paula and Iretie Browne. 1992 "Internalization and Constraint in Women's Subordination." Po. 97-

123 in Current Perspectives in Soctal Theory. Vol. 12, edited by B Agger. Greenwich. CT: JAI

Fararo. Thomas J 1989 "The Spint of Unufication in Sociological Theory." Sociological Theory 7(2): 175-90

Fararo, Ttomas J. and John Skvoretz 1986. "E-State Structurahism A Theoretical Method" Amertcan Sociological Review 51 591-602.

Gardner, Carol B. 1983 "Aspects of Gender Behavior in Public Places in a Small Southwestern Clity.' Doctoral dissertation, University of Pennsylvania.

Giddens, Anthony 1984 The Consititution of Soctety. Outine of the Theory of Structuration Berkeley University of Californa Press

Goffman, Erving 1959 The Presentation of Self in Everyaay Life New York: Anchor Doubleday.

1969 Strategic Interaction Philadelphıa Unversity of Pennsylvanta Press

197: Relattons in Public Microstudies of the Public Order. New York: Basic Books.

- 1974 Frame Analysss An Essay on the Organzzaton of Expenence Boston: Northeastern University

Press

_- 1977" "The Arrangement betweer the Sexes" Theory and Soctety 4. 301-36

1981 Forms of Talk Philadelphia. Unversity of Pennsylvania Press.

Habermas, Jurgen $198 \AA$ The Theory of Communcative Action, '/o! 1. translated by T McCarthy. Boston Beacon

Mancas, Peter 1974 The Death of the State. New York Putnam.

Pred, Allan 1951 "Power, Everyday Practice ard tre Discipline of Human Geography." Pp 30-55 in Space and Time in Geography. edited by A. Pred Lund, Sweden: CWK Gleerup

Span, Daphne 1992. Gendered Spaces Chapel Hill. University of North Carolina Press

1993 "Gendered Spaces and Women's Status" Soctological Theory 11(2): 137-51.

Strauss, Marcy 1990 "Sexist Speech in the Workplace." Harvard Civl Rights-Civil Liberties Law Review $25(1): 1-5:$

Unger. Roberto M. 1975. Knowledge and Poittce New York. Free Press

Vine, Ian. 1975. "Terrtonality and the Spatal Regulation of Interaction." Pp 357-87 in Organuzation of Behowor in Face-to-Face Interacton, edited by A Kendon. R M. Harns, and M R Key The Hague Mouton.

Wallace, Waiter L 1987 "Causal Images in Sociology" Soctological Theory 5(1) 41-46

Young, Irns M. 1990 "The Ideal of Communty' and the Polttics of Difference." $P_{\mathrm{P}}$ 300-23 in Femintsmi Postmodernısm. editec by L.J Nicholsen New York: Routledge

changed forever how we view or think about interaction between the sexes Because of the uncertanty now surrcunding the previcusly tacit norms of anterpersonal condict between males and females-especially as these pertain to the workplace - a new effort has been trutiated throughout business, governmeni, and the university to cocify ar: appropriate set of guidelines or norms for sach interaction. 